http://dx.doi.org/10.12775/szhf.2019.022

PAWE€ URBAŃSKI

Uniwersytet im. Adama Mickiewicza, Poznań, Polska

ORCID: 0000-0002-5179-1178

E-MAIL: PAZIU1984@WP.PL

\title{
Myślenie obrazu - malarstwo holenderskie XVII wieku jako ontologia świata widzialnego
}

Bowiem malarz zapomniat się w swym dziele i rzadko odwracał od płótna oczy,

by spojrzeć na lico swej żony. I nie chciał widzieć, że barwy kładzione przezeń na płótno, pochodza z jej policzków.

Edgar Allan Poe, Owalny portret

Na początku XVII wieku na terenie Europy Zachodniej dochodzi do reorganizacji porządku wiedzy. W naukach po raz pierwszy „świat rzeczy widzialnych" staje się przedmiotem godnym uwagi. W malarstwie tematyka religijna schodzi na drugi plan i zaczyna stanowić jedynie tło dla przedstawień innego typu, rzeczy bardziej przyziemnych - być może nawet banalnych. Przedmioty użyteczne, natura, życie codzienne, oto przykładowy repertuar obiektów, które jeszcze niedawno wydawały się niegodne uwiecznienia na 
płótnie malarskim. W Europie kształtuje się zatem nowy sposób rozumienia bytu. Jednakże pomimo narastającej presji procesów racjonalizacji, barok balansuje jeszcze pomiędzy „światem zaczarowanym” a rewolucją naukową. Centralnym miejscem tych przemian jest Holandia ${ }^{22}$.

Metoda archeologii historycznej pozwala rozcinać warstwy czasu nie według dzieł, autorów czy książek, lecz wzdłuż kształtujących się formacji wiedzy - porządków tego, co widzialne, i tego, co wypowiadalne. W taki też sposób traktuję siedemnastowieczne malarstwo holenderskie. Jednakże w niniejszej pracy archeologia nie zakreśla dla mnie podstawowego horyzontu refleksji, stanowi raczej krytyczny punkt wyjścia. Czym innym jest bowiem analiza pewnej formacji historycznej, która polega na odsłanianiu jej ukrytej episteme, a czym innym próba opisu materialnego wytwarzania efektów strukturalnych w danym miejscu. Zamierzam zatem zdjąć symboliczną powłokę z obrazu i prześledzić moment komponowania malarskich przedstawień od strony ontologicznej. W tym sensie historyczna rekonstrukcja recepcji dzieła malarskiego wymaga poszerzenia o analizę antropologiczną. Przez antropologię rozumiem problematyzację tych aspektów dzieła, które wydają się oczywistymi rezultatami procesu konceptualizacji poznania na metapoziomie. Innymi słowy, tam, gdzie filozofia widzi jedynie gotowe i nieredukowalne już struktury przedmiotowe i podmiotowe, które stara się ze

\footnotetext{
${ }^{22}$ Chciałbym w tym miejscu sprecyzować, co rozumiem przez termin „centralne miejsce przemian". Po pierwsze, sformułowanie to odsyła do kategorii geograficznych, które Fernand Braudel określił jako proces konstytuowania się centrum kapitalistycznej gospodarki-świata: „Amsterdam i jego długa dominacja - przez ponad półtora wieku - od Bałtyku po Lewant i Wyspy Korzenne wynika $\mathrm{z}$ niekwestionowanego panowania w handlu na północy Europy i z dość szybkiego opanowania wszystkich dalekowschodnich źródeł delikatnych przypraw; cynamonu, goździków itd. Ten quasi-monopol pozwala miastu niemal wszędzie działać z korzyścią dla siebie". (Fernand Braudel, Dynamika kapitalizmu, przeł. Bogdan Baran (Warszawa: Aletheia, 2013), 128). Warto jednak zauważyć, że ożywieniu w skali globalnej stosunków handlowych, które przynoszą Holandii ogromne korzyści, towarzyszył proces konstytuowania się nowych form wiedzy wizualnej, skupiający tak odmienne praktyki jak umiejętności sporządzania precyzyjnych map, kartografię, nawigację i przede wszystkim malarstwo. To właśnie te praktyki uczyniły z małej Holandii niekwestionowanego lidera w handlu międzynarodowym oraz ówczesne światowe centrum kultury i nauki. Można zatem powiedzieć, że pojęcie miejsca centralnego odnosi się nie tylko do procesu akumulacji kapitału, ale również do procesu akumulacji wiedzy (w szczególności zaś wiedzy wizualnej). Procesy te są względem siebie równoległe.
} 
sobą łączyć, a następnie próbuje nadać im najogólniejszy wyraz najczęściej za pomocą nieempirycznych pojęć, tam antropologia dostrzega rozbudowany konglomerat działań praktycznych.

Dlatego też celem niniejszej pracy jest pokazanie zależności pomiędzy materialną praxis wytwarzania obrazów, strukturami wiedzy nowoczesnej a ontologią świata. W swoim tekście definiuję obraz jako spontaniczny i nie w pełni kontrolowalny sposób integrowania różnorodnych praktyk w spójny system widzialności. Chodzi o proces odtwarzania zapośredniczeń, począwszy od momentu ich wyłonienia się na poziomie rozproszonych elementów jako prostych technik przetwarzania danych aż do ich zintegrowania i ustabilizowania w gotowej materii obrazu. Będę starał się pokazać, że ontologia świata widzialnego nie jest usytuowana ani w rzeczach, ani w podmiotach, lecz stanowi rezultat złożonego zbioru praktyk. Proponowana tu analiza przesuwa zatem punkt ciężkości $\mathrm{z}$ treści na formę, rozumianą $\mathrm{w}$ duchu McLuhanowskiej formuły medium is message. W swojej pracy pytam zatem o to, w jaki sposób obraz może stanowić system ontologicznej translacji przedmiotów, który w epoce klasycznej konstytuuje się jako określenie świata widzialnego, w szczególności zaś jako wzór obserwacji naukowej.

Przyjęcie zaprezentowanej perspektywy badawczej wymaga zdystansowania się od metod oraz form konceptualizacji przyjętych w ramach takich dyscyplin jak historia sztuki, estetyka czy epistemologia ${ }^{23}$. Nie oznacza to jednak, iż dyscypliny te nie stanowią dla mnie ważnego źródła inspiracji. Chodzi raczej o to, aby uchwycić dzieła sztuki nie tylko jako przedmioty szczególne ${ }^{24}$,

${ }^{23}$ Wymienione przeze mnie dyscypliny łączy to, że bardzo często posługują się sztywnymi dystynkcjami. Na przykład różnica pomiędzy figuratywnością przedstawień a materią obrazu, która implikuje określone założenia ontologiczne. $Z$ jednej strony suponuje podmiotową aktywność recepcji, czy też szerzej interpretacji, z drugiej zaś bierność i statyczność przedmiotu, który ma być interpretowany. Albo opozycja pomiędzy kształceniem (twórczością) a badaniem (poznawaniem według określonych reguł), która ukształtowała się dopiero wraz z podziałem nauk na nauki przyrodnicze i humanistyczne.

${ }^{24}$ Warto w tym miejscu przypomnieć, że ujmowanie dzieła sztuki jako przedmiotu szczególnego wynika z jego określonej kulturowo funkcji, powstałej na przecięciu pola akademickiego (profesjonalistów tworzących sztukę i piszących o sztuce) i pola rynkowego (nabywców, mecenasów, sponsorów, patronów), ale również w odniesieniu do technicznych środków reprodukcji oraz instytucji muzeum. W XVII wieku dzieło sztuki nie funkcjonuje zatem jako przedmiot szczególny, przynajmniej w takim sensie, że nie podtrzymuje go instytucja profesjonalistów od sztuki uświęcająca wartość dzieła nie tylko na poziomie estetycznym, ale również rynkowym. 
lecz także artefakty będące z jednej strony ontologicznie ustabilizowanymi depozytami złożonych praktyk, z drugiej zaś samoistnymi już rzeczami, które wprowadzają nowe możliwości w obszar formowania się wiedzy nowoczesnej. Będzie mnie zatem interesować również materialny aspekt sprawności przedstawień malarskich, określonych obiektami nie-ludzkimi. Stąd też do obrazów staram się podejść jak antropolog do nieznanego jeszcze sobie „etno-świata”. Swoje stanowisko badawcze sytuuję więc na pograniczu filozoficzno-antropologicznym ${ }^{25}$. Praca ta nie ma ambicji wyczerpującego przedstawienia problematyki wiążącej malarstwo holenderskie i filozofię, lecz jej zadaniem jest jedynie naświetlenie niektórych aspektów od strony praktycznej.

Praca składa się z czterech części. Na początek opisuję proces stabilizowania łańcucha referencji pomiędzy podmiotem a przedmiotem za pomocą urządzania optycznego - camera obscura, oraz funkcji, jaką pełniło ono w laboratorium Johannesa Keplera i atelier Jana Vermeera. Następnie skupiam się na materialnych efektach tej stabilizacji, a ich osiągnięcie nazywam „punktem widzenia znikąd”. W trzeciej części zastanawiam się nad procesem konstru-

Na ten fakt zwracają uwagę Pierre Bourdieu w książce Reguły sztuki, Walter Benjamin w tekście Dzieło sztuki w epoce jego reprodukowalności technicznej czy André Marlaux w klasycznym już eseju Muzeum wyobraźni.

${ }^{25}$ Chciałbym jednocześnie zaznaczyć, że pogranicze filozoficzno-antropologiczne rozumiem asymetrycznie, czyli bardziej jako antropologizowanie filozofii. Nie odwołuje się zatem do antropologii, która miałaby dostarczyć argumentacji np. na rzecz relatywistycznej koncepcji kultury w obrębie podejmowanej tu problematyki. Za Krzysztofem Abriszewskim termin „antropologizowanie filozofii" pojmuję jako próbę przebrania się filozofa za etnologa po to, by na nowo otworzyć problemy filozoficzne na gruncie praktyki (Krzysztof Abriszewski, „Szansa na powrót do empirii. O antropologizacji filozofii”, w: Antropologizowanie humanistyki. Zjawisko. Proces. Perspektywy, red. Jacek Kowalewski, Wojciech Piasek (Olsztyn: Instytut Filozofii Uniwersytetu Warmińsko-Mazurskiego w Olsztynie, 2009), 271). Sądzę, że istnieje tu szerokie pole do zastosowania. Na przykład fenomenologia odwołująca się do sfery przed-rozumienia, uprzedniej względem podziału na podmiot i przedmiot, na rzecz i ja, poznanie i to, co poznawane, stanowi badawczy przedsionek etnografii przed-tekstowej, którą można zdefiniować jako aktywne, ucieleśnione kształtowanie wiedzy, formujące się w postaci ciągu praktycznych rozpoznań. Antropolog korzysta z badań empirycznych, ponieważ najczęściej przedmiotem jego zainteresowań nie jest świat, który może uznać za swój własny labenswelt i poddać go fenomenologicznej epoche. Tak też jest, jak sądzę, z dziełami XVII wieku, które wymagają bardziej analizy empirycznej niż filozoficznego wglądu, choć rzecz jasna takie stanowisko ma swoje ograniczenia. 
owania warunków negatywności przedstawienia malarskiego oraz praktycznym zastosowaniem schematu. Na koniec zaś zajmę się zjawiskiem kolekcji, w którym wyróżniam dwie podstawowe cechy, ucieleśnienie i akumulację.

\section{Laboratorium artystyczne i naukowe atelier}

W XVII wieku nie istnieje jeszcze wyraźna granica pomiędzy nauką a sztuką. „Świat rzeczy widzialnych”, jaki wyłania się dzięki zasadzie odwzorowania ${ }^{26}$, stanowi wówczas autentyczne novum. Twierdzenie, że zmysły nas oszukują, a metafora wyznacza jedynie poetycką przestrzeń języka, żąda dopiero teoretycznego ugruntowania i zewnętrznego wyrazu. To, co można zobaczyć, oraz to, co można powiedzieć, musi być na nowo wytworzone, opracowane i poddane regularnej cyrkulacji, zanim stanie się powszechnym zasobem naukowej użyteczności. Siedemnastowieczne malarstwo poszukuje uniwersalnej techniki obrazowania świata, podobnie jak ówczesna nauka dąży do stworzenia uniwersalnego języka opisu rzeczywistości. Można zatem powiedzieć, że obraz (widzialne) i język (wypowiadalne) sprzęgają się w miejscu, w którym szeroko rozumiana "geografia” pozwala nanosić świat na dwuwymiarową przestrzeń kartki papieru bądź malarskiego płótna bez żadnych zniekształceń ${ }^{27}$.

\footnotetext{
${ }^{26}$ Foucault o zasadzie odwzorowania pisze, że był to festyn bytu i niekończącej się repetycji świata: „Ziemia powtarzała niebo, twarze odbijały się w gwiazdach, a zioła w łodygach kryły służące ludziom sekrety [...]. Odwzorowanie nigdy na sobie nie poprzestaje, ustala się dopiero wówczas, gdy odsyła do innego podobieństwa, które z kolei przyzywa podobieństwo nowe; tym samym każde $\mathrm{z}$ nich nabiera znaczenia dopiero poprzez akumulację pozostałych odwzorowań, kiedy przemierzony zostanie cały świat, aby usprawiedliwić najmniejszą z analogii i uznać ją wreszcie za pewną" (Michel Foucault, Słowa i rzeczy, przeł. Tadeusz Komendant (Gdańsk: Wydawnictwo słowo/obraz terytoria, 2006), 29-40). Wiedza ta jest równie bezgraniczna, co bezwiedna. Nic więc dziwnego, że rzeczy „tego świata” nie znajdują swojego miejsca w obrazach. Świat rzeczy widzialnych jeszcze nie został odkryty.

${ }^{27}$ Wprawdzie zasada un pictura poesis - jak wskazuje Mario Praz - była znana od czasów antycznych, to jednak u progu XVII wieku pomiędzy obrazem a słowem pisanym wykształca się zupełnie nowa relacja. (Patrz: Mario Praz, Mnemosyne - rzecz o powinowactwie literatury i sztuk plastycznych, przeł. W. Jankiel (Warszawa: PIW, 1981)).
} 
Wynalezienie „świata widzialnego” nie dokonuje się jednak za sprawą analizy percepcyjnej bezpośredniości, lecz dzięki eksperymentalnym próbom budowania systemu przedstawiania. Konstrukcje takie powstają zaś dzięki praktyce badawczej oraz procedurom, które w jej ramach są ujmowane w sztywne układy referencyjne. Te z kolei, aby mogły spełnić swoje zadanie, muszą zaistnieć jako samodzielne oraz samowystarczalne regularności, wolne od wszelkich związków z tradycją i autorytetem. Można zatem powiedzieć, że metoda, bo o nią tutaj chodzi, staje się właściwą podstawą wszelkiego rodzaju dociekań oraz gwarantem obiektywności. W XVII wieku wykształca się więc nowy porządek władzy wizualnej, nastawiony na wiedzę konkretu. W ten sposób rzeczywistość wchodzi w obszar namysłu przede wszystkim jako obraz.

Renesansowy wynalazek perspektywy linearnej Leona B. Albertiego był być może pierwszym narzędziem na drodze do tego, co dziś nazwalibyśmy reprezentacją. Pozwolił on bowiem oswoić trójwymiarową przestrzeń i zbliżyć jej sztuczne odwzorowanie do obrazu, jaki tworzy sobie oko ludzkie. Dzięki temu można było po raz pierwszy traktować malarstwo jako lustrzane odbicie rzeczywistości. Jednak olbrzymim obciążeniem dla tak skonstruowanej techniki obrazowania była nienaruszalność relacji, jaka zawiązuje się pomiędzy określonym punktem widzenia a przedstawieniem. W tym sensie perspektywa to wizualny przekład partykularnego spojrzenia zyskujący cechy intersubiektywnej komunikowalności dopiero na gruncie metody matematycznej. Spójność optyczna jako matematyczny efekt perspektywy zawiązuje się poza bezpośrednim obszarem przedstawienia i stanowi dla niego „niewidzialne rusztowanie", będące raczej przestrzenią abstrakcyjnych zabiegów niż spontanicznością spojrzenia. Dlatego też moment bezpośredniości jako subiektywnej i niezakłóconej komunikacji wizualnej nie jest możliwy bez zapośredniczonego momentu matematyzacji ${ }^{28}$.

\footnotetext{
${ }^{28}$ Warto zwrócić uwagę, że matematyka na polu malarstwa renesansowego odgrywa podwójną rolę, z jednej strony stanowi medium właściwej reprezentacji, z drugiej zaś umożliwia tworzenie anamorfoz, problematyzując tym samym aspekt matematyki jako właściwego medium reprezentacji. (Erwin Panofsky, Perspektywa jako forma symboliczna, przeł. Grażyna Jurkowlaniec (Warszawa: Wydawnictwo UW, 2008)).
} 
W perspektywie linearnej, bez względu na to, z jakiego dystansu i z jakiego kąta oglądamy obiekt, zawsze można go przenieść - dokonać jego translacji i otrzymać ten sam obiekt o innej wielkości, widziany z innego miejsca. W trakcie tej translacji wewnętrzne własności tego obiektu nie ulegają zmianie [...]. Dzięki perspektywie, dokładnie tak jak z mapą i z tych samych powodów, możliwe jest dokonanie nowego zestawu przemieszczeń: możesz zejść ze swojej drogi i wrócić ze wszystkimi miejscami, które minąłeś; wszystko jest zapisane w tym samym jednorodnym języku (długość i szerokość geograficzna, geometria), który pozwala zmieniać skalę, sprawia, że wszystko da się zaprezentować i do woli zestawiaćc ${ }^{29}$.

W tym sensie matematyka nie przezwycięża materialności obrazu, pozwala natomiast zachować wizualną spójność pomiędzy różnymi przestawieniami tego samego bądź innego obiektu. Wewnątrz technicznej konstrukcji perspektywy funkcjonuje zatem dialektyka widzialności i niewidzialności, czyli z jednej strony tego, co w bezpośredniości spojrzenia jest zawsze takie samo - posiada swoją matematyczną strukturę, z drugiej zaś tego, co pozwala zachować spójność, a co w samej bezpośredniości nie jest uchwytne. Uważam, że taka sytuacja wyznacza nieprzekraczalny próg subiektywności w myśleniu o świecie, problematyczny w obrębie samej perspektywy. Próg ten przekroczył dopiero Kepler, a wraz z nim Jan Vermeer.

W znakomitej książce The art of describing Svetlana Alpers pokazała ścisły związek pomiędzy uzyskanym w laboratorium Keplera obrazem rzeczywistym a krajobrazowym malarstwem holenderskim XVII wieku. Zwrot, jakiego dokonuje Kepler, można wyrazić w jego własnym stwierdzeniu: „aby zrozumieć nasze przedstawienia obiektów takich jak słońce, księżyc czy świat w ogóle, wpierw musimy pojąć, czym jest narzędzie, za pomocą którego te przedmioty stają się dla nas widoczne" ${ }^{30}$. Chodzi rzecz jasna o oko. Przedkeplerowskie teorie widzenia próbowały interpretować świat powstający na siatkówce oka tylko jako część łańcucha, który znajduje swój dalszy ciąg w mózgu i następnie pojawia się jako obraz mentalny. To jednak wikłało całą koncepcję w problematykę subiektywności. Klasyczna technika perspektywy,

\footnotetext{
${ }^{29}$ Bruno Latour, „Wizualizacja i poznanie. Zrysowywanie rzeczy razem”, przeł. Aleksandra Derra, Maciej Frąckowiak, Avant 3 (2012): 217.

${ }^{30}$ Cyt. za: Svetlana Alpers, The Art of describing (Chicago: University of Chicago Press, 1983), 35.
} 
mająca szerokie zastosowanie w malarstwie renesansowym, służyła jedynie do translacji tak skonstruowanego modelu widzenia. Dlatego też jedynie częściowo mogła być traktowana jako reprezentacja, gdyż to, co przedstawiane w taki sposób, nie posiadało jeszcze swego autonomicznego bycia jako coś dostępnego wszystkim w ten sam sposób. Perspektywa raczej multiplikowała partykularny punkt widzenia, który dopiero $\mathrm{w}$ „przestrzeni wystawienniczej"31 nabierał charakteru obiektywnego.

Dla Keplera modelami ludzkiego oka były różne urządzenia optyczne, głównie zaś camera obscura, co nie stanowiło dla nauki tamtego okresu niczego nadzwyczajnego. Człowiek XVII wieku to nie tylko res cogitans, ale również - jak twierdził nieco później Julien Offray de La Mettrie - maszyna składająca się ze sprężyn, drutów i metalowych rurek ${ }^{32}$. Również William Harvey, znany anatom i fizjolog, traktował stworzony przez siebie układ hydrauliczny jako model ludzkiego systemu krwionośnego. Z kolei Kartezjuszowi urządzenia pneumatyczne dostarczały wiedzy o funkcjonowaniu nerwów oraz pracy mięśni. Wyjątkowość camera obscura polega jednak na tym, że przedmiot ten był znany już od czasów antycznych i służył głównie jako narzędzie obserwacyjne w astronomii. Dopiero zaaplikowanie nowych rozwiązań technologicznych do starej konstrukcji tego narzędzia poszerzyło spektrum jego zastosowań. Otóż pod koniec XV stulecia w kamerze otworkowej zostaje umieszczona specjalnie spreparowana soczewka oraz ruchome lustro. Dzięki tym dwóm prostym zabiegom obraz, jaki pojawił się wewnątrz drewnianej ciemni, był przezroczysty i można go było zobaczyć niejako od drugiej strony. Z kolei zmiana położenia lustra umożliwiała kontrolowanie trajektorii promieni światła oraz dowolne odwracanie obrazu. Camera obscura stała się więc narzędziem optycznym, co niemal automatycznie pozwoliło Keplerowi na połączenie fizjologii oka $\mathrm{z}$ obszarem geometrii, a tym samym na tech-

\footnotetext{
${ }^{31}$ Pojęcie przestrzeni wystawienniczej umieszczam w cudzysłowie, ponieważ w tym okresie przestrzeń wystawiennicza tożsama jest z przestrzenią albo sakralną, albo prywatną. (André Marlaux, „Muzeum wyobraźni”, przeł. Irena Wojnar, w: Antologia współczesnej estetyki francuskiej, red. Irena Wojnar (Warszawa: PWN, 1980)).

32 Patrz: Julien Offray de La Mettrie, Człowiek maszyna, przeł. Stefan Rudniański (Warszawa: PWN, 1953).
} 
nologiczną egzemplifikację procesu widzenia ${ }^{33}$. Dzięki kamerze otworkowej widzenie stało się zatem przedmiotem obserwacji i w konsekwencji przestało być wyłącznie matematyczno-abstrakcyjnym odtworzeniem percepcji. Proces widzenia został bowiem odtworzony niejako na „zewnątrz”, a tym samym określony przez technologiczno-inżynieryjną repryzę percepcji. Można nawet powiedzieć, że widzenie zostało w ten sposób wykonane ręcznie.

Analogia pomiędzy funkcjonowaniem oka a działaniem aparatury optycznej umożliwia empiryczne prześledzenie dróg załamywania się promieni światła padających na soczewkę i lustro umieszczone w środku kamery otworkowej. Dzięki temu Kepler mógł poddać wytworzone dane procesowi matematycznej idealizacji ${ }^{34}$. Korzystając z postulatów ówczesnej dioptryki ${ }^{35}$, camera obscura pozwoliła na oddzielenie narządu wzroku od reszty ciała, zatrzymując tym samym obraz tylko na sztucznie wyosobnionej siatkówce. $\mathrm{W}$ tym sensie to, co rzeczywiste, odkłada się w formie przedstawienia w sposób możliwy do obliczenia oraz kontrolowania przez narzędzia pomiarowe. Kartezjański postulat, aby nie ufać zmysłom, został przezwyciężony przez „wyeksportowanie na zewnątrz” zarówno mechanizmu postrzegania, jak i tworzącego się na „siatkówce” obrazu, który poddany zostaje manipulatywno-użykowym procedurom rachowania. Słowem, to, co subiektywne, ulega tu obiektywizacji, przy czym sam ten proces należy rozumieć jako materialną praktykę badawczą, nie zaś jako czysty formalizm metody matematycznej.

Problem fizycznego tworzenia się obrazu zostaje zatem całkowicie oddzielony od psychologicznego traktowania percepcji. Od tej pory autora Harmonices Mundi nie interesuje już ani spojrzenie obserwatora, ani teoria

${ }^{33}$ Patrz: Wolfgang Lefèvre, „The Optical Camera Obscura. A Short Exposition”, w: Inside the Camera Obscura - Optics and Art under the Spell of the Projected Image, red. Wolfgang Lefèvre, https://www.mpiwg-berlin.mpg.de/Preprints/P333.PDF (dostęp: 10.11.2018).

${ }^{34}$ Warto w tym miejscu zwrócić uwagę na tekst Erwina Panofskiego zestawiający ze sobą style pracy naukowej Galileusza i Johannesa Keplera w perspektywie estetyki. (Erwin Panofsky, „Galileusz jako krytyk artystyczny. Postawa estetyczna i myśl naukowa”, przeł. Jan Białostocki w: Erwin Panofsky, Studia z historii sztuki (Warszawa: PIW, 1971)).

${ }^{35}$ Dioptryka była ówcześnie dziedziną wiedzy, która zajmowała się trzema obszarami. Po pierwsze, badała załamywanie promieni światła jako część optyki geometrycznej. Po drugie, dotyczyła fizyki oraz medycyny jako badania właściwości oka. Po trzecie, była nauką zajmującą się konstruowaniem przyrządów optycznych. Tak też rozumieli ją Kepler oraz Kartezjusz. 
postrzegania. Kepler powiada tak: „Rozważenie sposobów, w jaki przedstawienie obrazu organizowane jest przez siły ducha umieszczone w siatkówce oraz nerwach oka, zostawiam filozofom natury"36. W ten sposób rozdzielenie problemów stało się rozdzieleniem dziedzin zainteresowania. Obraz rzeczywisty, jaki został uzyskany na „siatkówce” sztucznego oka, był pierwszym obrazem, który można było rozpatrywać niezależnie od postrzegającego podmiotu. Alpers komentuje to w ten sposób: „Kepler nie tylko zdefiniował obraz powstający na siatkówce jako reprezentację, ale przede wszystkim umieścił w niej aktualność świata jako rzeczywistość tam odmalowaną" ${ }^{37}$.

Niemalże bliźniaczą techniką wytwarzania obrazów charakteryzuje się siedemnastowieczne malarstwo holenderskie, dla którego odpowiednikiem ludzkiej siatkówki jest biały kwadrat lub wąska przestrzeń okna. Są to zatem obrazy niezwiązane ze światem, choć stanowiące jego kontynuacje na płótnie - jak w twórczości Jana Vermeera. Autor Mleczarki, podobnie jak Kepler, korzystał z urządzenia camera obscura jako pustego miejsca odkładania się obrazu. Widok Delft to być może najbardziej popularny przykład przedstawienia skomponowanego jako „punkt widzenia znikąd”, gdzie spojrzenie malarza zostaje „usytuowane” jako (nie)miejsce, w którym może usadowić się każdy. Delft to fragment świata ściągnięty za pomocą aparatury optycznej i zamknięty w drewnianej skrzynce, a następnie nałożony na płótno.

Jeśli Kepler poradził sobie z postulatem Kartezjusza dotyczącym poznawczej ułomności zmysłów przez sprowadzenie przedstawienia do postaci obliczalnego a priori, to Veermer wygrał z Albertim przez ujednolicenie partykularnego spojrzenia do punktu odniesienia jako (nie)miejsca - „spojrzenia znikąd". Słowem i w jednym, i w drugim przypadku obraz zostaje uwolniony od subiektywnego związku, który krępował relacje przedstawiania. W ten sposób być może wyłania się pierwsza postać świata wiedzy obiektywnej Karla Poppera. Alpers pisze tak: „Oko Keplera i przedstawienia Vermeera przywołują obraz rzeczywistości pozbawiony ramy, który został nałożony na płaską powierzchnię, lecz nie za pomocą ludzkiej miary"38. Chodzi więc

\footnotetext{
${ }^{36}$ Cyt. za: Svetlana Alpers, The Art of describing (Chicago: University of Chicago Press, 1983), 35.

${ }^{37}$ Alpers, The Art of describing, 37.

${ }^{38}$ Svetlana Alpers, The Art of describing, 41. Warto w tym miejscu odnieść się do koncepcji Georges’a Didi-Hubermana, który krytykuje Alpers za jednowymiarowość takiej interpretacji.
} 
o obrazy, które powstają jakby bez udziału człowieka i tylko czekają na swojego widza. Dzięki takim obrazom świat ulega autonomizacji i - paradoksalnie - może funkcjonować bez ludzkiego udziału w świecie. Dużo racji miał Maurice Merleau-Ponty, który dostrzegał, że obrazy malarskie uzyskują szczególnego rodzaju sprawczość:

Z natury rzeczy trudno jest ustalić, „gdzie” jest to, co jest przedstawione na obrazie. Właściwie jest to niemożliwe, gdyż patrząc na obraz, nie tyle widzę jakieś ukazane w nim rzeczy, tak jak na co dzień widzę różne rzeczy rozpościerające się przede mną, jako coś naprzeciw mnie, ale widzę raczej według niego lub wraz z nim ${ }^{39}$.

\section{2. (Nie)miejsce przedstawienia}

Czym jest (nie)miejsce przedstawienia i jak działa spojrzenie znikad? Wydaje się, że miarodajnej odpowiedzi na to pytanie udziela Michel Foucault. Nie przez przypadek książkę Słowa i rzeczy otwiera esej o dziele Diego Valesqueza, z którego autor czyni swoistego rodzaju paradygmat dla formowania się nowoczesnych teorii wiedzy. Wyjątkowość La Maninas (1656) polega na tym, że to, co zostało tam przedstawiane, nie jest zawarte w obszarze samego przedstawienia, choć stanowi jego konstytutywną formę:

Jego zdaniem takie podejście zbliża autorkę The Art of describing w dużej mierze do ikonologii Panowsky’ego (analizę tej krytyki można znaleźć w: Andrzej Leśniak, Obraz płynny. Georges Didi-Huberman i dyskurs historii sztuki (Kraków: Universitas, 2010)). Nie mogę się z tym zgodzić, ponieważ powiązanie ze sobą praktyk naukowych, urządzeń optycznych i form przedstawialności niekoniecznie musi od razu implikować problematykę reprezentacji wraz z jej obiegową krytyką. Sądzę, że takie podejście w zasadniczy sposób wyklucza rozumienie nauki jako działania, które mobilizuje wokół siebie różnorodne zasoby, tworzy heterogeniczne sieci, renegocjuje warunki istnienia swoich przedmiotów za pomocą aparatury technologicznej itd. W moim przekonaniu podejście Alpers zyskuje na znaczeniu, jeśli rozszerzy się jej dociekania o intuicje z zakresu antropologii laboratorium. W tym sensie praca Svetlany Alpers, prowadzi raczej do pytania, w jaki sposób doszło do praktycznego ustabilizowania struktur poznawczych, które nieustannie same siebie rozpoznają w kategoriach reprezentacji.

${ }^{39}$ Maurice Merleau-Ponty, Oko i umysł, przeł. Stanisław Cichowicz (Gdańsk: Wydawnictwo słowo/obraz terytoria, 1996), 25. 
W chwili, gdy oczy malarza umiejscawiają widza w polu swego spojrzenia równocześnie wiążą go, zmuszają, aby wszedł w malowidło, wyznaczają mu miejsce, zarazem uprzywilejowane i narzucone [...]. Patrzący widzi swą niewidoczność, która dla malarza jest widocznością i przetworzona została w obraz ostatecznie niedostępny oku patrzącego [...]. Jest może w tym obrazie Velasqueza jak gdyby przedstawienie klasycznego przedstawienia, definicja przestrzeni, jaką to przedstawienie otwiera ${ }^{40}$.

Przede wszystkim widzialność nie jest kwestią zmysłów, a podmiot to jedynie jego pochodna. (Nie)miejsce stanowi definicję przestrzeni, jej wzór, który wskazuje na źródłowy związek z każdym możliwym miejscem jako miejscem przedstawienia.

W średniowieczu wyobrażenie przestrzeni polegało na hierarchicznym układzie miejsc z wyróżnioną pozycją „sfery niebiańskiej”. Podobnie w renesansie, kiedy ludzka perspektywa trwale wiązała przedstawienie z obecnością tego, kto przedstawia. Natomiast w XVII wieku proponuje się uchwycenie przestrzeni jako relacji pomiędzy równorzędnymi punktami, dzięki czemu przedstawianie rozmaitych przedmiotów występujących w różnych czasach i miejscach może być uważane za coś w rodzaju wehikułu obecności. Relacje pomiędzy obecnością i nieobecnością spaja bowiem jednolitość przekładu, możliwość wpisania $\mathrm{w}$ tę samą ramę odniesienia, jaką jest matematycznie określona przestrzeń. Wszystkie miejsca, chwile oraz przedmioty stają się równie ważne. $Z$ obrazu znika więc uprzywilejowane miejsce, $z$ którego spojrzenie ustanawia porządek tego, co można zobaczyć. Przestrzeń zostaje całkowicie podporządkowana obszarowi przedstawienia. $\mathrm{W}$ tym sensie również Widok Delft jest nie tylko konkretnym krajobrazem, lecz widokiem w ogóle, ideą, w którą każde konkretne miejsce dopiero powinno się wpisać. (Nie) miejsce stanowi więc wzór i jednocześnie możliwość niekończącej się repetycji przedmiotów świata widzialnego.

Często mówi się o mistrzach holenderskich, że malują swoje przedmioty tak jakby je „podglądali przez dziurkę od klucza”"41. „Podglądanie” wyraża tu obawę, że jakakolwiek forma obecności artysty mogłaby przedostać się w obszar obrazu i naruszyć delikatną powierzchnię przedstawionej rzeczy-

\footnotetext{
${ }^{40}$ Foucault, Słowa i rzeczy, 19-28.

${ }^{41}$ Patrz: Władysław Tomkiewicz, Piękno wielorakie. Sztuka baroku (Warszawa: PIW, 1971).
} 
wistości ${ }^{42}$. Inwencja to cecha, której artysta powinien się wystrzegać, jeśli chce, by jego praca miała wartość poznawczą, by stanowiła odzwierciedlenie uniwersalnych mechanizmów widzenia. Stąd też sformułowanie „podglądać przez dziurkę od klucza" tłumaczy po części dystans, jaki tworzy się pomiędzy tym, co postrzegane, a tym, co obserwowane. Ktoś, kto postrzega, staje się również twórcą swojego przedmiotu, jego konstytutywną częścią, która decyduje o sposobie jawienia się rzeczy. Z kolei ktoś, kto obserwuje, ma do czynienia z czymś, co zostało mu przedłożone w swym suwerennym byciu oraz może zostać przedłożone każdemu w ten sam sposób. Tutaj przedmiot odkleja się całkowicie od przedstawienia, w którym został przedstawiony, a jednocześnie zachowuje trwały i bezpośredni związek ze swoją przedmiotowością w strukturze wyobrażeniowej. To samo dotyczy podmiotu. Podmiot postrzegający dzięki „spojrzeniu znikąd” zostaje całkowicie wyeliminowany jako twórca przedstawienia oraz ponownie wprowadzony w jego obszar jako obserwator. Trwałość łańcucha referencyjnego, jaka wyłania się z układu pomiędzy przedmiotem a podmiotem, zostaje ustabilizowana przez samą konstrukcję reprezentacji, pomimo że materia obrazu bezlitośnie kawałkuje wszystkie części tego ciągu.

Pomiędzy obrazem a tym, co obraz przedstawia, pomiędzy przedstawieniem a przedmiotem oraz pomiędzy przedmiotem a podmiotem wytwarza się stały związek, który podtrzymywany jest przez zunifikowaną technikę przekładu. Można teraz bez problemu przemieszczać się w obrębie wszystkich części tego łańcucha bez żadnych strat. Dlatego przedstawiać to oswajać przedmiot $\mathrm{w}$ jego byciu przed-stawionym jako właściwym i najpełniejszym określeniu istoty tego, co istnieje. Przywołajmy w tym miejscu Martina Heideggera jako jednego z najbardziej przenikliwych krytyków nowoczesności, a w szczególności nauki:

\footnotetext{
${ }^{42}$ Na przykład Pierre Bourdieu zauważa, że maniera artysty wykształca się jako wartość dopiero w ramach zdobywania tzw. pola autonomii i stanowi odpowiedź na zmianę warunków rynkowych: „Nie bez znaczenia jest fakt, iż w miarę jak pole zdobywa większą autonomię, malarze zyskują coraz większą zdolność do tego, by uwidocznić i nadać wartość technice, manierze, czyli formie, temu wszystkiemu, co w przeciwieństwie do tematu, najczęściej narzuconego, należy im się na własność" (Pierre Bourdieu, Reguły sztuki, przeł. Andrzej Zawadzki (Kraków: Universitas, 2001), 482).
} 
Zyskać obraz czegoś znaczy postawić przed sobą sam byt, takim właśnie, jak $\mathrm{z}$ nim stoi sprawa, i w ten sposób postawiony stale mieć przed sobą. Ale brak tu jeszcze określenia decydującego o istocie obrazu. „Mamy obraz czegoś” znaczy nie tylko, że byt został nam w ogóle przedstawiony, lecz że stoi przed nami ze wszystkim, co do niego należy i co jest w nim zestawione, jako system. „Mieć obraz" - w tym dźwięczy też: rozeznanie, gotowość i odpowiednie nastawienie. Tam, gdzie świat czyni się obrazem, byt w całości zakłada się jako coś, na co człowiek się nastawia i co chce zatem pozwać przed siebie, mieć przed sobą i w ten sposób w zdecydowanym sensie postawić przed sobą. Światoobraz w rozumieniu istotnym nie oznacza więc obrazu świata, lecz świat pojmowany jako obraz ${ }^{43}$.

Zatem wytworzenie struktury, która wyznacza określoną pozycję podmiotu i jego poznawczy związek z przedmiotem, odbywa się poza bezpośrednią relacją tego, kto widzi, i tego, co widziane. Dopiero obraz zestawia te wszystkie rzeczy w określonej konfiguracji, a jednocześnie nastawia sam byt do bycia przed-miotem, którym podmiot może rozporządzać jako swoim własnym obiektem. I odwrotnie, dzięki tak skonstruowanemu obrazowi podmiot może być podmiotem poznającym w sensie nowoczesnego badacza. Innymi słowy: obraz wydobywa przedmiot jako w pełni zorganizowany byt, a podmiot jako byt wyposażony w trwałe dyspozycje poznawania przedmiotu jako przed-stawienia. Obraz splata rozproszone praktyki, w których podmiot konstytuuje się jako obserwujący, a przedmiot jako obserwowany, $\mathrm{w}$ jeden stabilny artefakt. $\mathrm{W}$ tym sensie moment bezpośredniego spojrzenia na obraz Vermeera musi być przejściem przez ślepy punkt, który podobnie jak w dziele Valesqueza, jednocześnie przedstawia to, co nie jest przedstawione. Nie chodzi tu jednak tylko o obecność widza tam, gdzie go nie ma, oraz jego nieobecność tam, gdzie się znajduje ${ }^{44}$.

Obraz to szereg dokonujących się poza obrębem przedstawienia ontologicznych zapośredniczeń, których nie sposób zredukować tylko do spojrze-

${ }^{43}$ Martin Heidegger, „Czas światoobrazu”, przeł. Krzysztof Wolicki, w: Martin Heidegger, Drogi lasu (Warszawa: Wydawnictwo „Czytelnik”, 1997), 77.

${ }^{44}$ „W zwierciadle widzę siebie tam, gdzie mnie nie ma, w nierealnej wirtualnej przestrzeni, która otwiera się za jego powierzchnią; jestem tam, gdzie mnie nie ma, rodzaj cienia, który daje mnie samemu moją widzialność, który pozwala mi oglądać siebie tam, gdzie jestem nieobecny” (Michel Foucault, „Heterotopie - inne przestrzenie”, przeł. Aleksandra RejniakMajewska, Teksty Drugie 6 (2005): 117-125). 
nia oraz metafory zwierciadła proponowaną przez Foucaulta. Widzialność, jaką oferuje obraz, jest już zawsze precyzyjnie ustrukturyzowaną przestrzenią, która sięga o wiele dalej niż to, co przedkłada do bezpośredniego oglądu lub precyzyjnej deskrypcji. Stąd też to, co można zobaczyć, nie pokrywa się $\mathrm{w}$ pełni z samym mechanizmem widzialności. Wystarczy pomyśleć o pracowni Keplera wypełnionej zestawami soczewek, książek oraz narzędziami pomiarowymi albo o atelier Vermeera, gdzie oprócz gamy pigmentów i pędzli o rozmaitej grubości włosia znajduje się również camera obscura. Sam obraz nie stanowi tu jeszcze warunku widzialności, stawką jest bowiem określona technika nałożenia go na płótno malarskie; zachowanie odpowiedniego kontrastu pomiędzy światłem a cieniem, organizacja przestrzeni oraz sposób redukowania skali uwzględniający intensywność i głębię kolorów ${ }^{45}$. Tego wszystkiego nie sposób uchwycić w bezpośredniej ulotności spojrzenia możliwą do prostego przełożenia na język obrazu. Precyzja, z jaką Vermeer „Zmniejsza świat”, wymaga trwałego substratu, który steruje uwagą malarza, pozwalając mu zatroszczyć się o najdrobniejsze detale. Wymaga również metody będącej „stabilnym rusztowaniem” dla całości przedstawienia. W tym sensie camera obscura bardziej tresuje oko, niż stanowi jego model, bardziej decyduje o pociągnięciach pędzla i doborze barw, niż czyni to nieskrępowana wola artysty.

Można tu zatem dostrzec dwie odmienne, choć subtelnie powiązane ze sobą praktyki. Po pierwsze, w obrębie nauki - praktyka Keplera pozwala rozłożyć obraz na „czynniki pierwsze”, a następnie poddać je regularnym powiązaniom w języku matematyki. Po drugie, w obrębie sztuki - praktyka Vermeera umożliwia precyzyjne przetworzenie na obraz tego, co rozłożyła nauka. Tak jak Kepler dokonuje analitycznego rozkładu przedstawienia w języku „geometrii naturalnej”, tak Vermeer na powrót przekształca poziom matematycznej idealizacji na język empiryczno-praktycznego sposobu obiektywizowania doznań wizualnych. Widok Delft jest zatem zmobilizowanym agregatem rozwiązań optycznych, umiejętnie „spakowanych” do postaci prostej

\footnotetext{
${ }^{45}$ Dobrze znanym urządzeniem optycznym (w XVII wieku), które pozwalało na sprowadzenie różnobarwności świata widzialnego do jego jakościowych gradacji, było tzw. zwierciadło Lorraina (Claude Lorrain, 1600-1682). To pomniejszające lusterko o przyciemnionej powierzchni. Dzięki niemu można było uzyskiwać efekt głębi i światła poprzez modelowanie tonem barwy.
} 
wizualizacji. Inaczej jeszcze: jest nieprawdopodobną złożonością heterogenicznych elementów wyartykułowaną jako coś prostego - obraz uchwytny w mgnieniu oka. Fakt ten znakomicie uchwycił Jean Luc-Marion:

Widzenie obrazu wymaga nie tylko tego, by został on namalowany przez malarza, lecz przede wszystkim tego, aby oglądający dopasował się do niego [...] posiadł dyspozycję, która bardziej od jakieś postawy teoretycznej zależy od pewnej pragmatyki ${ }^{46}$.

W tym sensie widzialność przetwarza, ale sama też jest zbiorem przetwarzalnym. Bycie rzeczy przedłożonych do oglądu nigdy nie redukuje się do wewnętrznych form ludzkiego przedstawienia, co najwyżej formy te mogą zostać praktycznie „zinternalizowane” jako gotowe dyspozycje ukształtowane przez technologie obrazu. $\mathrm{W}$ ten sposób niezwykle skomplikowane konstrukcje przedmiotowe mogą być traktowane jako z góry gotowe kategorie postrzegania rzeczy, czy też wprost jako wrodzone dyspozycje poznawcze.

To nie my patrzymy na obraz, to obraz patrzy na nas. Dzieje się tak, ponieważ (nie)miejsce przedstawienia nie znajduje swojej lokalizacji w całym spektrum „obiektywizującego" spojrzenia, a tym samym nie może pojawić się jako swój własny przedmiot. Prowadzi to do sytuacji, w której materialne warunki możliwości widzenia znajdują się poza zakresem wizualnego identyfikowania, są bowiem rozproszone w praktykach i artefaktach codziennej pracy. A jednak obraz decyduje o tym, co i w jaki sposób pozostaje na widoku przed-stawiającego myślenia. Tym samym to, co widać, i to, co można powiedzieć, na powrót daje się uchwycić tylko w formie epistemologicznej bezpośredniości podmiotu i przedmiotu. Ta redukcja odpowiada za ontologiczny przeskok od świata rzeczy do świata teorii, za pomocą której ów świat jest ujmowany. Pod tym względem epoka baroku jest równie nowoczesna, jak „zaczarowana”.

${ }^{46}$ Jean Luc-Marion, „Donacja i to, co dane”, przeł. Wojciech Starzyński, w: Fenomenologia francuska. Rozpoznania. Interpretacje. Rozwinięcia, red. Jacek Migasiński, Iwona Lorenc (Warszawa: Wydawnictwo IFiS PAN, 2006), 465. 


\section{Warunki negatywności i schemat graficzny}

Zbigniew Herbert, miłośnik siedemnastowiecznego malarstwa holenderskiego, w swoich szkicach tworzy apokryficzny list, którego autorem jest Vermeer, adresatem zaś znany przyrodnik Antoni van Leeuwenhoek ${ }^{47} \mathrm{Na}$ wstępie tej korespondencji zostaje opisana wizyta w laboratorium naukowca, który umożliwia artyście obserwowanie przez mikroskop kropli wody:

W czasie tej demonstracji śledziłeś badawczo i, jak mi się zdaje, z zadowoleniem moją konsternację. Było między nami milczenie. A potem powiedziałeś bardzo wolno i dobitnie: „Taka jest woda, mój drogi, taka, a nie inna”. Pojąłem, co chciałeś przez to wyrazić: że my, artyści, utrwalamy pozory, życie cieni, kłamliwą powierzchnię świata, a nie mamy odwagi ani zdolności dotrzeć do istoty rzeczy. Jesteśmy, by tak rzec, rzemieślnikami pracującymi w materii złudy, gdy Ty i Tobie podobni - jesteście mistrzami prawdy ${ }^{48}$.

Powszechną reakcją na kryzys obiektywności jest powrót do sztuki jako jedynej powierniczki prawdy. Dlatego to, co zostało opisane przez Herberta, świadczy o pomieszaniu porządków. Archeologia posiada swoją teraźniejszość i nie musi wcale przybierać schematu wertykalnego, w którym poziomy rozwoju wiedzy określają również hierarchie ważności. Należy pamiętać, że w XVII wieku nauka i sztuka mają te same ambicje. Naukowiec i artysta nie toczą ze sobą sporów o prawdę, lecz wspólnie ją wytwarzają. Więcej nawet: w epoce klasycznej z „porządku prawdy” nie wyklucza się proroków, kapłanów oraz muz. W malarstwie zaś przedmioty, które zaraz staną się obiektami „prawdziwej” nauki, funkcjonują obok fantazji i objawień na tym samym poziomie „obiektywnej” przedstawialności.

Przedmiotem prac Jacoba de Ghyena II czy Jana van Kessela są m.in. kwiaty, niewielkie płazy oraz owady. Nie stanowią one jednak alegorii, jak często się uważa, lecz powiększony obraz uzyskany pierwotnie za pomocą szkła powiększającego lub mikroskopu. W XVII wieku artysta rzadko maluje rzeczy,

${ }^{47}$ Antoni von Leeuwenhoek (1632-1723) zwany jest powszechnie ojcem mikrobiologii. Zajmował się nie tylko nauką, ale również produkcją mikroskopów i szkieł powiększających.

${ }^{48}$ Zbigniew Herbert, Martwa natura $z$ wędzidłem (Warszawa: WiP, 2015), 144-145. 
częściej naśladuje urządzenia optyczne. To one mówią mu, co i w jaki sposób ma namalować. Natura epoki baroku jest technologiczną mimesis. Czy można wyobrazić sobie zoom bez mikroskopu? W jaki sposób powiększyć ruchliwe oraz ledwie widoczne gołym okiem żyjątko do wielkości ludzkiej dłoni, tak aby każdy jego detal został odpowiednio wyeksponowany? W jaki sposób zachować przy tym stabilność łańcucha referencji i nie być posądzonym o szerzenie fikcji?

Tak jak malarstwo krajobrazowe dzięki wykorzystaniu camera obscura było nie tylko próbą poprawnego przedstawienia, lecz również udanym eksperymentem zmniejszania świata, tak mikroskop służy do jego powiększania. Manipulowanie skalą jest dziś tak powszechne, że spoglądanie pod tym kątem na barokowe obrazy może przybrać charakter zapominającego uwspółcześniania - jakby powiedział Heidegger ${ }^{49}$. Biorąc pod uwagę skromność środków technicznych, wizualne zmniejszanie i powiększanie przedmiotów musiało robić w tamtym czasie ogromne wrażenie. Jednak nie tylko skala i przywiązanie do szczegółu stanowią podstawową cechę tych przedstawień. Zamiłowanie do obrazów idzie w parze z naukową dociekliwością. W XVII wieku artysta i naukowiec to często ta sama osoba. Przykładem jest Maria Sibylla Merian (1647-1717), znakomita przyrodniczka i utalentowana malarka, autorka słynnej pracy Metamorphosis insectorum Surinamensium ${ }^{50}$, w której opisała oraz zilustrowała cykle rozwojowe owadów i roślin egzotycznych. Obrazy zawarte w tej niezwykłej książce równie dobrze można nazwać dziełami sztuki, co odpowiednio spreparowanym materiałem empirycznym. Z kolei w słynnej pracy Micrographia ${ }^{51}$ Roberta Hooka (1635-1703) niezwykle precyzyjne rysunki powiększonych insektów stanowią integralną część materiału badawczego.

Istnieją przynajmniej dwie charakterystyczne cechy przedstawień tamtego okresu, zyskujące charakter reprezentacji. Nazwę je roboczo: negatywnością oraz schematem. Pozwalają one wyprowadzić określone konsekwencje prak-

\footnotetext{
${ }^{49}$ Patrz: Martin Heidegger, Bycie i czas, przeł. Bogdan Baran (Warszawa: PWN, 2004).

${ }^{50}$ Całość można zobaczyć pod adresem: https://archive.org/details/Metamorphosisin00Meri (dostęp: 12.09.2018).

${ }^{51}$ Całość można zobaczyć pod adresem: http://www.gutenberg.org/ebooks/15491 (dostęp 12.09.2018).
} 
tyczno-poznawcze w odniesieniu do konstytuowania się przedmiotów jako przed-stawień.

Po pierwsze: negatywność. Co widać na tych obrazach? Przede wszystkim białe tło, a na nim równomiernie rozmieszczone rośliny, owady i płazy. $\mathrm{Na}$ jednym z obrazów van Kessela bez żadnych problemów można rozpoznać charakterystyczne ubarwienie oraz szczegóły budowy anatomicznej Papilio machaon (paź królowej), Melolontha hippocastani (chrabąszcz kasztanowy) czy Chorthippus biguttulus (konik pospolity). Owady przedstawione są z różnych punktów widzenia, raz z góry, a raz z profilu. Niektóre są powiększone, a niektóre ukazano w naturalnej wielkości. Przypominają raczej entomologiczną kolekcję albo zdjęcia umieszczone w podręczniku do biologii niż dzieło sztuki. Lecz co w tym zadziwiającego? Jak zauważa Foucault, formacja, jaka rodzi się u progu epoki klasycznej, opiera się głównie na krytyce zasady odwzorowania. Wytwarza ona $\mathrm{w}$ ten sposób podstawy własnej episteme. Z dzieł wizualnych musi więc zniknąć niemal wszystko, co stanowiło o kształcie poprzedniej wiedzy. Jeszcze w XVI wieku język i obraz sytuują się po stronie rzeczy i porządkują wiedzę według zasad sympatii, sąsiedztwa, pokrewieństwa oraz analogii, które były zdolne jedynie „przepisywać” świat. $\mathrm{W}$ tym sensie znaki stanowią nierozerwalną część rzeczy, nie sposób więc ułożyć ich w innym porządku, niż rozkładają się w przestrzeni „naturalnej”. Bajka, obserwacja, dokument - wszystko zlewa się w jedno. Dlatego też białe tło niejako jednym cięciem pozbawia uprzednią formację podstaw:

Od XVII wieku obserwacja jest zmysłowym poznaniem, któremu przypisywane są ściśle negatywne warunki. To oczywiście wykluczenie tego, co zasłyszane, ale również wykluczenie smaku i zapachu, ponieważ ze względu na swoją nieokreśloność i zmienność nie pozwalają one na analizę wyodrębnionych elementów, która byłaby do przyjęcia przez wszystkich ${ }^{52}$.

Oto pierwszy poziom negatywności, który nie tylko znakomicie współgra z geometryczną linearnością obrazów, ale przede wszystkim zmusza przedmioty, by wskazywały same na siebie. Rzeczy wyosobnione ze swych „zwyczajowych” związków, które najwyraźniej krępowały autentyczność ich bycia i nie pozwalały zamanifestować się im w całej swej okazałości, teraz zostają

\footnotetext{
${ }^{52}$ Foucault, Słowa i rzeczy, 125.
} 
w pełni wyeksponowane. Taki przedmiot przedstawienia, niezakłócony ani manierą malarza, ani problemem pokrewieństwa czy sympatii, pozwala na to, by stematyzować go jako w pełni autonomiczny byt, poznawczo „czysty” w swym jawieniu się. Czyż nie o powrót do rzeczy samych upomina się cała nowożytna filozofia? Nawet tam, gdzie dzieła malarskie pozbawione są białego tła, jak choćby na płótnach Ottona Marseusa van Schriecka czy Williama Kalfa, warunek negatywności zostaje podtrzymany przez starannie zaaranżowaną scenę, pozbawioną zbędnych dekoracji, gdzie główną rolę odgrywają rzeczy. To już nie są obrazy przeznaczone do interpretacji albo starające się opowiedzieć jakąś historię, lecz obrazy, które wymagają uważnych obserwacji i precyzyjnych opisów. Podobnie jak teksty naukowców, przedstawienia te mają być znaczące w sposób jawny i bezpośredni. Alpers wprost odnosi warunek negatywności do empiryzmu angielskiego, a zwłaszcza do postulatu Francisa Bacona, by do przedstawień rzeczy nie wprowadzać nadpobudliwego umysłu, który powinien wystrzegać się idoli. Czystość zmysłowego języka żąda więc wizualnej negatywności w stosunku do obiektu, do którego się odnosi.

Po drugie: schemat. Sztuka epoki baroku jest jeszcze pozbawiona dylematów, jakie zarysują się dopiero w XIX wieku. Niechęć do szablonu czy różnice pomiędzy konwencją a inspiracją to problemy natury historycznej, dotyczące zwłaszcza autonomii pola sztuki, które w XVII stuleciu jeszcze nie istnieje. Dla nas schemat wydaje się tylko zwykłym narzędziem dla młodych adeptów sztuki malarskiej, podczas gdy w XVII wieku pozwala on na otwarcie ontologicznej struktury świata. Obok Jacoba de Ghyena II, którego prace przypominają podręcznik dla początkujących malarzy, w 1643 roku w Amsterdamie Crispyan van de Passe publikuje książkę pod tytułem La Luce del depigere. Jest to pierwsza encyklopedia malarstwa, zawierająca zbiór znanych już technik oraz szereg praktycznych porad, jak malować. Znajdujemy tam m.in. schematy uszu, dłoni, drzew, roślin, przeróżnych zwierząt oraz rzeczy codziennego użytku. Wszystkie są rozrysowane w sposób geometryczny. Schemat jawi się tutaj jako idealna struktura przedmiotów, którą należy dopiero wypełnić cechami indywidualnymi. Dzieło van de Passego to nic innego jak leksykon natury - powie Ernst Gombrich ${ }^{53}$. To prawda, schemat, będąc jednym

${ }^{53}$ Patrz: Ernst Gombrich, Sztuka i złudzenie, przeł. Jan Zarański (Warszawa: PWN, 1981). 
z wielu narzędzi sztuki malarskiej, istniał na długo przed epoką klasyczną. Nie było ono jednak brane pod uwagę jako istotna część wytwarzania wiedzy oraz grunt dla sporządzania reprezentacji. Nigdy przedtem nie nabrało charakteru normatywnego w odniesieniu do sztuki malarskiej. Należy więc zapytać o konsekwencję przeszczepienia schematu w obszar, gdzie jeszcze ani język, ani mechanizm widzialności nie okrzepły na tyle, by stworzyć solidny korpus uniwersalnej metody badawczej.

Zauważmy, że jeśli precyzja obrazu potrafi już wskazywać na określone indywidua i jednocześnie pragnie być reprezentacją, poznaniem dostarczającym wiedzy o świecie, to musi również dysponować pewną metafizyką. Schemat to konkret pozwalający z prostego rysunku wyprowadzić abstrakcyjne pojęcie struktury przedmiotu jako ogólnej kategorii poznawczej. Przez strukturę należy rozumieć kompozycję i połączenie fragmentów, które jako wzór można przypisać określonej dziedzinie przedmiotów. Materia jest zbyt kapryśna i nieposłuszna, by móc ją pozostawić samej sobie. Należy ją więc zmusić do przybrania odpowiednich proporcji. Słowem: trzeba ją zdyscyplinować za pomocą schematu. Od rzeczy muszą odpaść tym razem cechy jednostkowe oraz barwa, które mogą zakłócać transparentność struktury i wprowadzić obserwatora w błąd. Schemat ma uwzględniać tylko niezbędne wyróżniki widzialne. Mikroskop z kolei pozwala na wprowadzenie do pojęcia struktury tych elementów, których nie sposób dostrzec gołym okiem. Na przykład strukturą w przypadku botaniki będzie po prostu korzeń, łodyga, liście i owoc. Przejrzystość tego podziału na tyle precyzyjnie określa konstrukcje przedmiotu, że każdą z wydzielonych części zaczyna się postrzegać jako wynik zmiennych, kolejno: kształtu, ilości, rodzaju, relacji i wielkości. Te zaś $\mathrm{w}$ zestawieniu z wizualnym schematem umożliwiają tworzenie podziałów taksonomicznych. Znać bowiem strukturę to wiedzieć, co mierzyć oraz jakie elementy ze sobą można zestawiać, by otrzymać miarodajny wynik. Schemat to instrukcja obsługi świata przyrody. Przywołajmy raz jeszcze Heideggera:

[Badanie] dokonuje się w ten sposób, że w pewnym obszarze bytu, na przykład w przyrodzie, projektuje się określony schemat procesów przyrodniczych. Projekt wytycza sposób, w jaki postępowanie poznawcze ma być powiązane z otworzoną właśnie dziedziną. To powiązanie stanowi rygor badania. Projektując schemat i określając rygor, postępowanie zapewnia sobie w obrębie 
bytowego obszaru dziedzinę przedmiotową [...]. Proces przyrodniczy staje się widoczny dopiero w polu widzenia schematu ${ }^{54}$.

Schemat, nie reprezentując żadnego poszczególnego przedmiotu, automatycznie przekształca konkretne indywiduum w egzemplarz określonego rodzaju - otwiera dziedzinę. Pojęcie abstrakcyjne (schemat) skrywa więc określoną figurę zmysłową, sprawiając, że w tym, co ogólne, uobecnia się to, co poszczególne, i odwrotnie: w tym, co poszczególne - to, co ogólne. Dlatego też schemat jest czymś niezwykle poręcznym. Dopiero po przepuszczeniu przez czarno-biały układ linii rzeczy dają się oswajać w podziale na rzędy, klasy i gromady. Dopiero gdy proporcje są ustalone, rzecz można wypełnić jakościami w sposób właściwy jako indywiduum i przystąpić do opisu atrybutów jako części wspólnych dla danej klasy. To, co współ-dane na sposób obiektywny, musi być wpierw współ-wykonane w obrębie techniki rysunku. W taki sposób Otto Marseus van Schrieck maluje kwiaty oraz owady - jego dzieła to finezyjna encyklopedia botaniczno-entomologiczna.

Warunki negatywności oraz schemat to metafizyka, którą uprawia się w sposób empiryczny. Gruntownie wykształcony przyrodnik epoki baroku z góry wie, gdzie patrzeć, by znaleźć to, czego szuka. Schemat zaprzęgnięty w obszar szeroko rozumianej praktyki badawczej to nie tylko technika przekształcania rzeczy w ogólny system teoretyczny, ale również ontologiczny środek dyscyplinowania przedmiotów, praktyczny sposób ich wytwarzania jako obiektów poznawczych. Każde malarstwo - powiada Merleau-Ponty wytwarza swoją teorię bytu ${ }^{55}$.

\section{Kolekcja - czyli ucieleśnienie i akumulacja}

Chyba nikt nie opisał fenomenu kolekcji lepiej niż Krzysztof Pomian w znakomitej książce Zbieracze i osobliwości. W swojej pracy autor zwraca uwagę na dzieła holenderskich mistrzów, dla których przedmiotem stają się gabinety wypełnione różnościami:

${ }^{54}$ Heidegger, „Czas światoobrazu”, 69-71.

${ }^{55}$ Merleau-Ponty, Oko i umyst, 25. 
Każdy gabinet jest jak mikrokosmos, pomniejszony wszechświat. Gabinet przedstawiony na obrazie jest więc całym wszechświatem, który daje się objąć jednym spojrzeniem, wszechświatem, by tak rzec, sprowadzonym do wymiaru oka... Redukcja ta idzie jednak w parze z dbałością o szczegóły i z dokładnością w oddaniu przedmiotów... Jak gdyby chciano pomniejszyć rzeczy składające się na świat, by można było objąć je wszystkie jednym spojrzeniem, nie zmieniając przy tym ich cech najtrudniej uchwytnych... ${ }^{56}$

Cóż jednak zadziwiającego jest w samym fenomenie kolekcji? Jak wskazuje Pomian, kolekcja to przede wszystkim problem klasyfikacji bytów, a tak jako mikrokosmos powinna zawierać reprezentatywne elementy dla skali makro. W swej pierwotnej formie kolekcja przybiera zaskakujące porządki. Na przykład podział można zacząć od wyliczenia ptaków jako rzeczy należących do żywiołu powietrza, a skończyć na bytach nieożywionych, do których zaliczano rośliny. Można również rozpocząć od „rzeczy przemienionych w kamień” i starożytnych rzeźb przez medale wojskowe aż do przedmiotów morskich. Propozycji klasyfikacji jest tyle, ile kolekcji. Lecz jedno je wyróżnia, przyjmują charakter hierarchiczny, który zostaje wyznaczony przez rzadkość obiektu. Im rzadszy okaz jest, tym wyżej znajduje się w hierarchii. W tym sensie, jak zauważa również Beata Frydryczak, kolekcje „towarzyszą przemianom świadomościowym i filozoficznym poglądom na świat, stanowiły (zwłaszcza między XV i XVIII w.) solidną podstawę poznawczą i badawczą nauk"57. I właśnie ten aspekt kolekcji jako technicznego narzędzia zaprzęgniętego do służby nauce interesować nas będzie najbardziej.

Nim obraz i słowo odkleiły się od rzeczy, to właśnie osobliwości przyrody, a nie wykryte w niej regularności, decydowały o kształcie wiedzy. Kości olbrzyma, róg jednorożca, fragment mumii - oto przykładowe przedmioty wyznaczające właściwy porządek rzeczy nie tylko w przestrzeni gabinetu zbieracza. Jednak zasada odwzorowania, która z wyjątku tworzyła pojęcie struktury, wraz z nastaniem „epoki kolekcji” - jak powiada Pomian - zaczyna błyskawicznie się zwijać. Istnieją dwie fundamentalne przyczyny tego procesu. Po pierwsze, jeszcze pod koniec XVI wieku wiedzieć znaczyło tyle,

${ }^{56}$ Krzysztof Pomian, Zbieracze i osobliwości, przeł. Andrzej Pieńkos (Gdańsk: Wydawnictwo słowo/obraz terytoria, 2012), 67-68.

${ }^{57}$ Beata Frydryczak, Świat jako kolekcja (Poznań: Wydawnictwo Fundacji Humaniora, 2002), 146. 
co przemierzać świat w jego nienaruszalnej istocie. Wówczas rzeczywistość żądała odwzorowania, a nie refleksji. Stąd też kolekcja początkowo wydaje się chaosem. Narusza bowiem boską strukturę rzeczywistości, brutalnie wyrywa jej fragmenty i gromadzi według porządków, jakie podpowiadają same rzeczy. W świecie przedmiotów na krótką chwilę wybucha więc rewolucja. Nie można jej już jednak zdusić za pomocą boskiej transcendencji. W kolekcji dziedziny Naturalia i Celestia powoli zaczynają stanowić dwa odrębne porządki. Po drugie, fakt gromadzenia różnorodnych przedmiotów w jednym miejscu powoduje, że siłą rzeczy są one porównywane ze sobą. Gabinet kolekcjonera odpowiada białemu tłu, jako warunkowi negatywności. Walter Benjamin powie nawet, że dla kolekcji rozstrzygające są dwa momenty. Pierwszy sprawia, że obiekty zostają uwolnione od swoich funkcji. Drugi powoduje, że kolekcja staje się próbą zawiązania nowych relacji pomiędzy rzeczami w celu przezwyciężenia irracjonalności nagiego bytu, jaki jest efektem samego zbioru ${ }^{58}$. Na niewielkiej przestrzeni płótna malarskiego bądź pokoju spotykają się więc rzeczy, które wcześniej nie miały prawa się ze sobą zetknąć. W tym sensie kolekcja to po prostu okazja do wykrycia nowych podobieństw i zależności. Być może zwierzęta oraz rośliny, które na pierwszy rzut oka nie mają ze sobą nic wspólnego, po zestawieniu okażą się członkami tej samej rodziny bądź klasy. Jednak przejście od kolekcji do „racjonalnej taksonomii” wymaga pośrednictwa obrazu i pracy schematu.

Proponuję zdefiniować pojęcie kolekcji przez dwie cechy. Pierwsza to ucieleśnienie, druga to akumulacja.

Zacznijmy od ucieleśnienia. Owady Kessela, szkice mikroskopowo powiększonych insektów Robert Hooka, encyklopedia malarstwa van de Passego czy ilustracje Marii S. Meriam to też kolekcje, których charakterystyczną cechą jest to, że przedmioty w nich przedstawione mogą być ze sobą dowolnie zestawiane, są bowiem sporządzone według tej samej zasady organizującej. Warunki negatywności, schemat i kolekcja to praktyczne narzędzia wytwarzania przedmiotów, które uzupełniają się wzajemnie. Jeśli warunek negatywności mówi o tym, że przedmiot ma wskazywać sam na siebie, to tylko po to, by następnie za sprawą kompozycji strukturalnej wyznaczonej przez

${ }^{58}$ Patrz: Walter Benjamin, Pasaże, przeł. Ireneusz Kania (Kraków: Wydawnictwo Literackie, 2005). 
schemat eksplodował zestawem nowych różnic i podobieństw. Wskazywanie na siebie oznacza więc po prostu bycie zestawialnym, gotowość do włączenia w inny układ odniesień niż porządek odwzorowania. Wystarczy już tylko dostawiać - jakby powiedział Heidegger. Różnice i podobieństwa można dostrzec wyłącznie w obrębie odpowiednio przygotowanej kolekcji. Warunki negatywności, schemat i kolekcja jako samo-organizujący się mechanizm widzialności są gwarantem utrzymania spójności myślenia w bezpośredniej procedurze empirycznego porównywania przedmiotów. Niczym na pierwszych stronach Fenomenologii ducha u Georga W. F. Hegla, gdzie prawda pewności zmysłowej ulega dialektyce i krąży nieustanie od przedmiotu do podmiotu i z powrotem, nigdzie nie znajdując swojego miejsca. Zupełnie tak jakby ontologia miała się dopiero zagnieździć w przedmiocie, nadać mu właściwej cielesności przez praktykę i użycie odpowiednich narzędzi.

Oto naukowy sensus communis według Foucaulta:

Dokumentami tej nowej historii nie są inne słowa, teksty bądź archiwa, ale określone przestrzenie, gdzie zestawia się rzeczy - zielniki, kolekcje, ogrody; miejscem nowej historii jest bezczasowy prostokąt, gdzie, pozbawione wszelkiego komentarza $[\ldots]$ stojące obok siebie rzeczy prezentują swoje widzialne powierzchnie - pogrupowane wedle wspólnych cech [...]. Powiada się często, że na tworzenie ogrodów botanicznych i kolekcji zoologicznych przekłada się nowa ciekawość do roślin i zwierzą ${ }^{59}$.

Katalogowanie, indeksowanie, zestawianie, archiwizowanie - oto nowa pasja epoki klasycznej. Wydaje się, że doskonale ten moment uchwycił już w 1617 roku Jan Brueghel Starszy, malując obraz, który został nazwany Alegorią zmysłu wzroku. Niezwykłe w tym obrazie jest to, że widok na świat otwiera tam zamknięta przestrzeń pokoju wypełnionego kolekcją rzeźb, przyrządów mierniczych, wypchanych zwierząt, lunet, globusów oraz fantastycznymi postaciami amora i muzy. Fantazja miesza się tam z rzeczywistością. Obraz Brueghela sugeruje, że wszystkie rzeczy, te przyziemne i te należące do świata ducha, muszą najpierw przejść przez porządek przedstawienia, by stać się tym, czym są w swej istocie, tak jakby tylko mechanizm przedstawienia mógł nadać ciało zarówno temu, co eteryczne, jak i temu, co zwyczajne. Jest to

${ }^{59}$ Foucault, Słowa i rzeczy, 124. 
więc dzieło, które sytuuje się gdzieś w połowie drogi pomiędzy rozpadem porządku odwzorowania a rewolucją naukową. John Low, analizując barokową rzeźbę Giovanniego Lorenza Berniniego przedstawiającą ekstazę św. Teresy, zwraca uwagę, że duchowość pozbawiona jest w niej cech kontemplacji, jakiegokolwiek dystansu do świata zmysłowego. To, co mistyczne, wyraża się tam w cielesnym spazmie rozłożonym na nieliczone detale. Duchowa ekstaza św. Teresy nie ma więc niczego poza ucieleśnioną „sferą niebiańską”, która znajduje się w świecie, a nie ponad nim. „W epoce baroku - pisze Low - doświadczenie [duchowe - P. U.] oznacza utrzymywanie cielesnej zmysłowości $\mathrm{z}$ dala od form ascetycznych. Być może powinniśmy uznać, że dualizm duszy i ciała tu nie działa albo działa inaczej” ${ }^{30}$. Zauważmy, że również u Barucha Spinozy w Traktacie teologiczno-politycznym doświadczenia duchowe i objawienia są tłumaczone jako zjawiska ucieleśnione w mikropraktykach społecznych, stanowią dosłownie mistykę codzienności. Podobnie obraz Brueghela przedstawia obok siebie fantastyczną figurę amora i muzy oraz lunetę, globus, przyrządy miernicze itd. i nie ma pomiędzy nimi różnicy, która wskazywałaby, że owe przedmioty należą do odmiennych porządków. Stąd też w konstrukcji tego przedstawienia nie ma różnic ontologicznych, jest ono bowiem spójne w swej rozciągłości. Heterogeniczność bytów zostaje tu poprzedzona homogenizacją $\mathrm{w}$ obszarze przedstawienia, ale również odwrotnie, ontologiczna homogeniczność zostaje zakorzeniona w nieredukowalnej heterogeniczności.

Duch i przyroda jako przedmiot nowoczesnej nauki spotykają się zatem w tym samym miejscu, są efektem performatywnego spektaklu, zostają ucieleśnione $\mathrm{w}$ materii przedmiotów za sprawą praktyki. Można się pomiędzy nimi przemieszczać, tak jak robi to Spinoza w filozofii, Brueghel w malarstwie, a Bernini w kamieniu. Słowem: duchowość ducha epoka baroku wytwarza tak samo jak przedmiotowość przedmiotów.

Wraz z ucieleśnieniem istotną dla kolekcji cechą okazuje się akumulacja. To, że praktyki przedstawieniowe dają znakomite efekty poznawcze, nie znaczy jeszcze, że rzeczy istnieją tylko po to, by je przed-stawiać, oraz że w tym przed-stawieniu wyczerpują one swój sposób bycia. To, że każdą rzecz można

${ }^{60}$ John Low, „Assembling the Baroque”, http://hummedia.manchester.ac.uk/institutes/cresc/ workingpapers/wp109 (dostęp: 15.01.2019). 
wpisać w określony układ praktyk, nadając jej tym samym właściwą cielność, wcale nie oznacza, że miarą wszystkiego jest tu przed-stawienie. Pomian, badając liczne archiwa, zauważa, że nie tylko przedmioty podlegają akumulacji w zbiorach. Oto przykład jednego z wielu zestawień, jakie analizował autor:

Borel interesuje się przede wszystkim wydarzeniami, rzadkimi, a nawet wyjątkowymi epizodami, które według niego tworzą historię. Stąd waga portretów wielkich ludzi: ułożone w serie, pozwalają lepiej niż cokolwiek innego mieć przed oczami całość dziejów [...]. W XVI i XVII wieku gabinetów podobnych do posiadanego przez Borela są w Europie setki, jeśli nie tysiące ${ }^{61}$.

Obok świadectw przyrody oraz rzeczy osobliwych akumulacji podlega również czas i przestrzeń. Również dzieło Brueghela, Alegoria zmysłu $w z r o k u$, to kolekcja obrazów i przedmiotów zawarta w jednym przedstawieniu. Są to rzeczy należące do różnych światów, miejsc i czasów. Zupełnie tak jakby określona metoda nakładania farby na płótno rozkładała jednocześnie wielość czasów i wielość miejsc w jednym ciągu przedstawienia, nadając tym samym widzeniu linearną formę przejścia. Podobnie jak w modelu racjonalności mechanicznej, wyjaśnienie zjawiska również posiada linearną strukturę następstwa. Czas pomieszczony i zatrzymany w obrazie pozwala na swobodne przechodzenie z pewnego wtedy do określonego teraz. Podobnie też to, co nazwaliśmy (nie)miejscem przedstawienia, które odgrywało rolę wzoru przestrzeni, sprawia, że odległe tam zostaje każdorazowo przekształcone na obecne $t u$. Wszystko nagle staje się dostępne w zasięgu wzroku, bez ruszania się z miejsca. Obraz sprawia, że odległe czasy i miejsca tworzą teraz spójny system widzialności, spektrum uniwersalne pod względem czasowo-przestrzennym.

Jednakże owo spektrum jest nieco kłopotliwe. Otóż przedstawienie, będąc wzorem przestrzeni, samo zajmuje w niej miejsce jako obraz - rzecz materialna. Dochodzi więc do sytuacji, w której uniwersalność przedstawienia nie ma szans na realizację wyłącznie w obrębie struktury wyobrażeniowej. Wzór przestrzeni nie może bowiem zawierać się w przestrzeni, którą sam zajmuje jako obraz. W epoce baroku czas i przestrzeń to łączność, a nie rama odnie-

${ }^{61}$ Pomian, Zbieracze i osobliwości, 78. 
sienia $^{62}$. Na przykład Maria S. Merian wyrusza z Holandii do Surinamu, by badać cykle rozwojowe owadów tropikalnych. Jej praca nie zostanie jednak wydana na terenie, na którym prowadzi swoje badania, i nie będzie służyć tamtejszej ludności. Merian powraca do Europy z mnóstwem obrazów i opisów, które opublikuje dopiero w Amsterdamie w 1705 roku. Zobrazować można wszystko i wszędzie, lecz sam obraz staje się czytelny tylko w jednym miejscu. Innymi słowy, przyroda tropikalna musi wpierw zostać praktycznie przetworzona, a następnie przetransportowana do Europy, by być tym, czym jest. W tym sensie uniwersalność to raczej dobrze ustabilizowana sieć lokalnych praktyk. Nawet jeśli mają one zasięg globalny, to są raczej czymś, co Bruno Latour nazywa lokalnym wszędzie ${ }^{63}$. Dzieje się tak dlatego, że sam wzór przestrzeni nie jest jeszcze utożsamiany z porządkiem podmiotowej refleksyjności. Oznacza to, że sama refleksyjność stanowi również łączność ucieleśniającą się pomiędzy rzeczami i praktykami. Jeśli w baroku można jeszcze mówić o zakłopotaniu w związku z uniwersalnością struktur wiedzy i świata, jaki wytwarza, to już oświecenie nie pozostawi w tej kwestii żadnych wątpliwości.

Dlatego też obrazy zawierające kolekcję innych obrazów - tak jak w przypadku dzieła Brueghela i Merian - mogą być traktowane jako próba wizualnego zdefiniowania filozofii transcendentalnej Kanta, w szczególności zaś autoreferencyjnej struktury podmiotu transcendentalnego. Obraz w obrazie przezwycięża bowiem ociężałość własnej materii na rzecz złożonej formy przedstawieniowej. Można powiedzieć, że jest zobiektywizowanym szeregiem materialnych praktyk w przedmiocie, przeznaczonym do percepcji. Obraz gwarantuje w ten sposób stabilną relację samoodniesienia, czyli tego, co widziane w samej relacji widzenia. Pozwala tym samym na odłożenie czasu i przestrzeni w obszar przed-ustawnej struktury doświadczenia, które Kant nazwie później formami naoczności. Sama zaś materialność struktury przedstawieniowej zostanie zredukowana do rozbłysku jedności apercepcji.

\footnotetext{
${ }^{62} \mathrm{~W}$ zakresie problematyki uniwersalności jako rozmiaru i złożoności odsyłam do znakomitego tekstu Johna Lowa pod tytułem „And If the Global Were Small and Nonkoherent? Method, Complexity and Baroque": http://www.lancaster.ac.uk/fass/resources/sociology-online-papers/papers/law-and-if-the-global-were-small.pdf (dostęp: 21.01.2019).

${ }^{63}$ Patrz: Bruno Latour, Splatajac na nowo to, co społeczne, przeł. Aleksandra Derra, Krzysztof Abriszewski (Kraków: Universitas, 2010).
} 
Skupienie wykładni bytu w uproszczonej jedności przed-stawienia, które wraz z nastaniem nowożytności stopniowo zagnieżdża się po stronie podmiotu, albo szerzej: podmiotowych formach wiedzy, sprawia, że sam podmiot w swej przedstawiającej funkcji zabezpiecza swój własny byt jako przed-stawienie, a przed-stawienie jako byt w ogóle. Oświecenie będzie stanowiło kulminację tego procesu.

\section{Zakończenie}

Widzenie wydaje się najbardziej bezpośrednią, najprostszą oraz najbardziej spontaniczną formą komunikowania się ze światem. Fantastyczność sztuki baroku pozwala nam na nowo przemyśleć struktury wiedzy nowoczesnej, która wykształca się w oparciu o tę właśnie formę. W szczególności zaś malarstwo określa moment, w którym widzialność konstytuuje się jako probierz praktyki naukowej ${ }^{64}$. To przecież na takich terminach jak „obserwacja”, „fakty”, „naoczność” czy „doświadczenie” badacze koncentrowali swoją uwagę w celu uprawomocnienia skomplikowanych teorii naukowych i filozoficznych. W swojej pracy - odwołując się do antropologii - starałem się pokazać, że te pojęcia, które często są postrzegane jako nieredukowalne podstawy konstytuowania się nowoczesnych struktur wiedzy, w gruncie rzeczy są dobrze ustabilizowanym agregatem praktyk przyjmującym samoistną i samoodtwarzającą się formę. W konsekwencji szansę opisania tych praktyk można wyartykułować na poziomie „myśli nieoswojonych”. W tym sensie barok można rozumieć jako ontologiczną korektę oświeconego rozumu, jego monosubiektywnej racjonalności, epistemocentryzmu, a przede wszystkim humanistycznie zorientowanej nauki, która od samego początku nie dostrzega, że dystynkcja pomiędzy wiedzą nowoczesną i nienowoczesną należy do wewnętrznej problematyki nowoczesności.

Zunifikowana postać wiedzy jako czystej teorii nigdy nie daje nam bowiem wglądu w performatywny spektakl, jaki kryje się za ontologią świata widzial-

${ }^{64}$ Patrz: Modernity and Hegemony of Vision, red. David Michael Levin (Los Angeles: University of California Press, 1993). 
nego. Obraz wcale nie gwarantuje zdystansowanej postawy wobec świata, lecz jako złożony z heterogenicznych elementów artefakt ów świat przedstawia na wielu poziomach. Dzieje się tak, ponieważ widzieć, obserwować, rejestrować fakty czy po prostu doświadczać oznacza nie tylko dysponowanie określonym nastawieniem badawczym, ale przede wszystkim zaangażowanie w szereg uspołecznionych praktyk, instytucji, niesformalizowanych działań, które sytuują się poniżej progu świadomości, choć nieustannie są odtwarzane w samym procesie poznawczym. Dlatego też można powiedzieć, że ponowne zaczarowanie świata nowoczesnego fantastycznością barokowej sztuki skutkuje jego odmitologizowaniem na poziomie epistemologicznym. Niemniej jednak restytucja magicznego realizmu $u^{65}$ - pozwolę sobie na pewne nadużycie w stosunku do pojęcia Timothy’ego Mortona - nie jest powrotem do przed-nowoczesnej niewinności. Wręcz przeciwnie, zachęca nas do ponownego przemyślenia zależności pomiędzy działaniem praktycznym, strukturami wiedzy a ontologiczną strukturą świata nowoczesnego.

\section{Bibliografia}

Abriszewski Krzysztof. 2009. „Szansa na powrót do empirii. O antropologizacji filozofii". W: Antropologizowanie humanistyki. Zjawisko. Proces. Perspektywy, red. Jacek Kowalewski, Wojciech Piasek. Olsztyn: Instytut Filozofii Uniwersytetu Warmińsko-Mazurskiego w Olsztynie.

Alpers Svetlana. 1983. The Art of Describing. Chicago: University of Chicago Press.

Benjamin Walter. 2005. Pasaże, przeł. Irenausz Kania. Kraków: Wydawnictwo Literackie.

Bourdieu Pierre. 2001. Reguły sztuki, przeł. Andrzej Zawadzki. Kraków: Universitas.

De La Mettrie Julien Offray. 1953. Człowiek maszyna, przeł. Stefan Rudniański. Warszawa: PWN.

Fernand Braudel. 2013. Dynamika kapitalizmu, przeł. Bogdan Baran. Warszawa: Aletheia.

Foucault Michel. 2005. „Heterotopie - inne przestrzenie”, przeł. Aleksandra Rejniak-Majewska. Teksty Drugie 6.

${ }^{65}$ Patrz: Timothy Morton, Realistic Magic. Object, Ontology, Casuality (Chicago: University of Michigan, 2013). 
Foucault Michel. 2006. Słowa i rzeczy, przeł. Tadeusz Komendant. Gdańsk: Wydawnictwo słowo/obraz terytoria.

Frydryczak Beata. 2002. Świat jako kolekcja. Poznań: Wydawnictwo Fundacji HUMANIORA.

Gombrich Ernst. 1981. Sztuka i złudzenie, przeł. Jan Zarański. Warszawa: PWN.

Heidegger Martin. 1997. Drogi lasu, Jan Mizera, Krzysztof Wolicki, Józef Tischner. Warszawa: Wydawnictwo „Czytelnik”.

Heidegger Martin. 2004. Bycie i czas, przeł. Bogdan Baran. Warszawa: PWN.

Herbert Zbigniew. 2015. Martwa natura $z$ wędzidłem. Warszawa: WiP.

Latour Bruno. 2010. Splatajac na nowo to, co społeczne, przeł. Aleksandra Derra, Krzysztof Abriszewski. Kraków: Universitas.

Latour Bruno. 2012. „Wizualizacja i poznanie. Zrysowywanie rzeczy razem”, przeł. Aleksandra Derra, Maciej Frąckowiak, Avant 3.

Lefévre Wolfgang. „The Optical Camera Obscura. A Short Exposition”. Dostęp 10.11.2018. https://www.mpiwg-berlin.mpg.de/Preprints/P333.PDF.

Leśniak Andrzej. 2010. Obraz płynny. Georges Didi-Huberman i dyskurs historii sztuki. Kraków: Universitas.

Low John. „And If the Global Were Small and Nonkoherent? Method, Complexity and Baroque". Dostęp 21.01.2019. http://www.lancaster.ac.uk/fass/resources/ sociology-online-papers/papers/law-and-if-the-global-were-small.pdf.

Low John. „Assembling the Baroque”. Dostęp: 15.01.2019. http://hummedia.manchester.ac.uk/institutes/cresc/workingpapers/wp109.

Jean Luc-Marion. 2006. „Donacja i to, co dane”, przeł. Wojciech Starzyński. W: Fenomenologia francuska. Rozpoznania. Interpretacje. Rozwinięcia, red. Jacek Migasiński, Iwona Lorenc. Warszawa: Wydawnictwo IFiS PAN.

Marlaux André. 1980. „Muzeum wyobraźni”, przeł. Irena Wojnar. W: Antologia współczesnej estetyki francuskiej, red. Irena Wojnar. Warszawa: PWN.

Modernity and Hegemony of Vision, red. David Michael Levin. Los Angeles: University of California Press. 1993.

Morton Timothy. 2013. Realistic Magic. Object, Ontology, Casuality. Chicago: University of Michigan.

Panofsky Ervin. 1971. Studia z historii sztuki, przeł. Jan Białostocki. Warszawa: PiW.

Panofsky Ervin. 2008. Perspektywa jako forma symboliczna, przeł. Grażyna Jurkowlaniec. Warszawa: Wydawnictwo UW.

Poe Edgar Allan. 1999. „Owalny portret”. W: Edgar Allan Poe, Opowieści niesamowite, przeł. Bolesław Leśmian. Warszawa: Wydawnictwo Muza.

Pomian Krzysztof. 2012. Zbieracze i osobliwości: Paryż - Wenecja: XVI-XVIII wiek, przeł. Andrzej Pieńkos. Gdańsk: Wydawnictwo słowo/obraz terytoria.

Praz Mario. 1981. Mnemosyne - rzecz o powinowactwie literatury i sztuk plastycznych, przeł. Wojciech Jakiel. Warszawa: PIW. 
Tomkiewicz Władysław. 1971. Piękno wielorakie. Sztuka baroku. Warszawa: PIW.

\author{
Abstract \\ Thinking of image - XVII century Dutch painting as ontology \\ of the visible world
}

The purpose of this paper is to demonstrate unobvious connection among material praxis of producing a painting, structure of modern knowledge, and ontology. I claim that a painting is something more than a picture on canvas that we can adore or investigate in some other way. The Baroque art, with its new topics and new forms of depiction, inaugurated modernity as fresh, visual knowledge separated from the enchanted world order, but this separation was not something obvious and complete. I accept this incompleteness as a clue to investigate in the sense Bruno Latour expressed it in his famous sentence; we have never been modern. A painting, as I define it, rules and constructs sight but simultaneously covers the whole performative (enchanted) spectacle which generates it on the level of material mediations. It means that direct relation between the subject and the object does not correspond with the obtained epistemological or even aesthetic scheme of analysis. Therefore, anthropology of painting needs ontological reflection constituted on a blurred border between the enchanted and the disenchanted world.

Keywords: painting; ontology; praxis; modernity; technology; Baroque.

\title{
Streszczenie
}

\section{Myślenie obrazu - malarstwo holenderskie XVII wieku jako ontologia świata widzialnego}

Celem niniejszej pracy jest pokazanie nieoczywistego związku pomiędzy materialną praxis wytwarzania obrazu, strukturą wiedzy nowoczesnej a ontologią świata. Twierdzę, że obraz jest czymś więcej niż przedstawionym na płótnie malarskim malowidłem, który możemy podziwiać. Sztuka baroku ze swoimi nowymi tematami oraz sposobami przedstawiania $\mathrm{z}$ jednej strony inauguruje nowy typ wiedzy wizualnej, zasadniczo różniący się od zaczarowanego porządku wiedzy przednowoczesnej, z drugiej strony jednak różnica ta nigdy nie była ani oczywista, ani kompletna. W swojej pracy przyjmuje tę niekompletność jako trop w sensie takim, jaki nadałby mu Bruno Latour, że nigdy nie byliśmy nowocześni. Obraz, tak jak go rozumiem, zarządza i konstruuje spojrzenie, lecz jednocześnie zakrywa 
performatywny (zaczarowany) spektakl, który generuje strukturę spojrzenia na poziomie materialnych zapośredniczeń, co oznacza, że bezpośrednia relacja pomiędzy podmiotem a przedmiotem nie pasuje ani do epistemologicznego, ani nawet estetycznego schematu analizy. Dlatego też antropologia obrazu wymaga refleksji ontologicznej osadzonej na niewyraźnej granicy pomiędzy zaczarowanym a odczarowanym światem.

Słowa kluczowe: obraz; ontologia; praxis; nowoczesność; barok. 